\title{
TWO NEW SPECIES OF EMELINUS FROM ARIZONA
}

\section{(COLEOPTERA : ADERIDAE) ${ }^{1}$}

\author{
By FLOYd G. WERNER \\ University of Arizona, Tucson, Arizona
}

The two species of Emelinus described here bring the known species in our fauna to four. Others assignable to the genus have been described from Central and South America but, so far, none from the Old World. Since the last general work on Nearctic species of Aderidae, by Casey in $1895,{ }^{2}$ there has been only one significant publication affecting our fauna, a reclassification on a World basis by Baguena Corella in 1948. ${ }^{3}$ Whereas neither Pic nor Champion felt that the genera set up by Casey could have more than subgeneric or species-group significance, Baguena Corella has made an effort to split up the huge and diversified assemblage of species already assigned to Xylophilus or Hylophilus, raising Emelinus not only back to generic rank but setting it off in a separate tribe, Emelinini. Baguena Corella also shows good reason for using the family name Aderidae, thus ending a triple tie for the names Euglenidae, Xylophilidae and Hylophilidae.

Baguena Corella's definition of Emelinus restricts it to species with the head totally visible from above and with the male antennae flabellate from the fourth segment. The two new species fit this diagnosis but differ in some details possibly of generic significance from $E$. melsheimeri (Lec.) and E. ashmeadi Csy. In these the antennae angle beyond the third segment in the male and the rami of segments six through ten originate near the apex of the segments. The two species from Arizona do

${ }^{1}$ Published with a grant from the Museum of Comparative Zoology at Harvard College.

${ }^{2}$ Ann. N. Y. Acad. Sci. 8:772-809.

3"Estudio sobre los Aderidae," Instituto de Estudios Africanos, Madrid. 
not have the antennal angling and the rami all originate before or near the middle of the segments. Casey noted the angling in $E$. ashmeadi but it was not mentioned by Champion in the Central American species, nor does it appear in his figures. It seems most likely that the two Arizona species are more closely related to those described from Central America than they are to melsheimeri and ashmeadi, the two species from which a genotype must be selected.

Both the species described below were collected by the author, in company with Dr. George D. Butler, Jr., in Ramsey Canyon, Huachuca Mts., huachucanus mostly below the "box" and butleri entirely about one-half mile above the "box." The presence of both species was detected by random sweeping of vegetation alongside the path. In each case additional specimens were obtained by more intensive sweeping and examination where the first specimens were taken. All the butleri specimens came from an area less than twenty feet across and mostly from maple leaves. Almost all the huachucanus came from a similar area, from leaves of a broad-leaved oak. Since both trees are widely distributed in the canyon, it seems likely that the small areas of abundance were in some way tied in with emergence of the adults from a very restricted habitat. Undisturbed individuals of both species appeared simply to be resting on the upper surfaces of the leaves; there was no sign of feeding of any kind.

Key to the Nearctic Species: Males

1. Antennae angled backward at apex of segment III; rami of antennal segments VI-X arising near apex of segments, of such lengths that the rami and segment XI form an almost evenly rounded series across their ends. Elytra with a variegated pattern of darker markings

Antennae not angled at apex of segment III; all rami arising before middle of segments, almost uniform in length, not making a rounded series across their ends 
2. Eyes almost contiguous in front E. ashmeadi Csy. Eyes separated in front by $2 / 5$ their maximum width E. melsheimeri (Lec.)

3. Rami all less than $1 / 5$ the total length of the antenna. Elytra brown, with a variegated paler pattern .... E. huachucanus sp.n. Some of the rami almost $2 / 5$ total length of antenna. Elytra very dark brown, marked with reddish at the humeri E. butleri sp.n.

I have before me a single male of melsheimeri I collected in LaSalle Co., Illinois, June 29, 1938, and compared several years ago with the type in the LeConte collection. A male of ashmeadi collected at Gainesville, Florida, March 4, 1947, by H. V. Weems, Jr., has been loaned by Mr. C. A. Frost. What I take to be the female of this species is before me from Fairfax Co., Virginia, collected in June, 1923, by Mr. Quirsfeld, on loan from the Cornell collection.

It seems inadvisable to attempt a key to the females at this time, there being little to compare them with in other genera. The peculiar structure and pubescence at the base of the pronotum, as described under butleri, may be diagnostic of the genus. The female of ashmeadi has antennal segment II very sharply, obliquely truncate at base. In females of butleri and huachucanus segment II is simple. What appears to be still another undescribed species is represented by a single female from Sta. Rita Mts., Arizona, July 30, 1938, collected by D. J. \& J. N. Knull. This is in most respects like the female of huachucanus but has the elytra pale and has the eyes more deeply emarginate than the female of that species. The emargination is almost ogival rather than rounded, as it is in huachucanus and butleri. This specimen is being returned to the collection of the Ohio State University.

\section{Emelinus butleri sp.n}

Very dark brown, the humeri of the elytra broadly rufous. Bases of legs pale. Sparsely and quite evenly clothed with short cinereous pubescence. Rami of male antennae short, all less than $2 / 5$ as long as antenna and 
quite even in length, only just perceptibly thickened apically.

Holotype male: Length (based on length of head to front margin of eyes, plus length of pronotum and length of elytra) $3.65 \mathrm{~mm}$.; maximum width of elytra ca. $1.1 \mathrm{~mm}$. Antennae $2.10 \mathrm{~mm} ., 0.57$ as long as the body. Head suborbicular, deeply and evenly punctured, with moderately sparse, decumbent, cinerous pubescence. Length, to bottom margin of eyes, $0.56 \mathrm{~mm}$.; width across eyes, $0.73 \mathrm{~mm}$. Fronto-clypeal suture deep; clypeus and labrum more finely and sparsely punctured and pubescent than the rest of the head. Eyes deeply excavated for the antennae, $0.42 \times 0.33 \mathrm{~mm}$., separated from each other by $0.09 \mathrm{~mm}$. A smooth border surrounds the eyes, somewhat widened behind. Last segment of maxillary palpi securiform, $0.24 \times 0.14 \mathrm{~mm}$. Last segment of the labial palpi, as in all the species treated here, oval and with a conspicuous membranous sensory area beneath.

Antennae very dark brown, with sparse, suberect pubescence. Segment I is barrel-shaped; II short and stout, the dorsal the shortest side; III subcylindrical, slightly expanded at the apex; IV-X with dorsal rami, curved slightly toward the apex of the antenna, and slight ridges anteriorly near the apices. The ramus of IV originates near the base, of $x$ just beyond the middle of the segment and there is a gradual transition in between. Segment XI has a knob 0.63 of the distance from the base, this knob most prominent posteriorly. Measurements (in relation to a total length of 1,000 units, from segment I to XI, length/ thickness ): $99 / 46,37 / 41,109 / 37,92 / 25,86 / 25,86 / 25$, $86 / 25,86 / 25,86 / 22,86 / 22,236 / 55$. Segment XI is slender at base, 23 units, gradually expanding to knob, 55, then abruptly contracting, with a short apical section 25 units wide. Rami (at same ratio) IV to $\mathrm{x}: 238,308,337,326$, $320,295,246$. The individual rami are ca. $0.03 \mathrm{~mm}$. wide at base, expanded feebly at apex to ca. $0.05 \mathrm{~mm}$.

Pronotum subcampanulate, the effect accentuated by a tuft of several setae at the posterior angles. Length 0.65 $\mathrm{mm}$., width $0.64 \mathrm{~mm}$. Base slightly indented at middle, 
the indention flanked by a pair of feeble elevations on the disc. The pubescence is peaked posterior to these elevations, leaving the slight median indentation free of setae. Surface shiny, densely and deeply punctured and sparsely, evenly pubescent, as on head. Scutellum truncate, densely punctured. Elytra almost parallel-sided, evenly, conjointly rounded behind, $2.44 \mathrm{~mm}$. long, $0.87 \mathrm{~mm}$. wide at humeri, ca. $1.1 \mathrm{~mm}$. at widest. Basal $25 \%$, except along suture, rufous. This zone is not sharply defined. Omoplate area slightly, conjointly elevated. Surface shiny, deeply punctured but not as densely as on pronotum, the middle of the punctures ca. $0.05 \mathrm{~mm}$. apart. (On the disc of the pronotum they are ca. $0.03 \mathrm{~mm}$. apart). All of the dorsal punctures have rounded bottoms. Pubescence correspondingly sparser, longer, about $0.09 \mathrm{~mm}$. long, decumbent, all cinereous, not at all influenced by the ground color.

Underside dark brown, the coxae and trochanters, as well as the inner edge of the front and middle femora, paler. Suture between the first and second apparent abdominal sternites distinct all the way across. Posterior femora thickened beyond middle, ca. 2 times as thick as at base. First segment of the posterior tarsi $0.44 \mathrm{~mm}$. long, the rest together 0.28 ; ratio of the first to the rest $1.54: 1$.

Allotype female: differs from the male most notably in the absence of rami on the antennae, also in the size of the eyes. Segments IV-X are truncate basally and apically, as in the male, but there is no sign of any projections in the places where the rami occur in that sex. These segments are articulated anterior to the middle. The antennae are $1.66 \mathrm{~mm}$. long, on a specimen $3.9 \mathrm{~mm}$. in total length, or 0.43 the length of the body. The individual measurements (to a total length of 1,000 units) are: 129/61, 61/46, $109 / 42,92 / 46,84 / 46,77 / 46,77 / 48,77 / 48,77 / 48,77 / 60$, $138 / 77$. It will be noted from these figures that segment $\mathrm{XI}$ is of more normal proportions than in the male, where $\mathrm{XI}$ appears, at first glance, to be just one more ramus on the flabellate antennae. The eyes are $0.44 \mathrm{~mm} . \times 0.22 \mathrm{~mm}$. and are separated by $0.22 \mathrm{~mm}$. The posterior tarsi are 
slightly shorter than in the male. Segment I is $0.38 \mathrm{~mm}$. long, the rest together $0.20 \mathrm{~mm}$., the ratio of $\mathrm{I}$ to the rest 1.94: 1 .

Holotype male and allotype female: Ramsey Canyon, Huachuca Mts., Cochise Co., Arizona, July 12, 1955, F. G. Werner \& G. D. Butler, deposited in the MCZ. 6 male and 1 female paratypes from the same locality, July 12 and 13, 1955, in the collections of the University of Arizona, the U.S. National Museum, California Academy of Sciences and the author. 1 male paratype Madera Canyon, Sta. Rita Mts., Arizona, July 31-Aug. 1, 1948, W. Nutting \& F. Werner, in the collection of the author, and 1 female Mud Springs, Sta. Catalina Mts., Arizona, July 17-20, 1916, $-6,500^{\prime}$; being returned to Ohio State.

There is very little variation in the series, the length ranging from $3.3 \mathrm{~mm}$. to $3.65 \mathrm{~mm}$. in the males and $3.9 \mathrm{~mm}$. to $4.3 \mathrm{~mm}$. in the females. This species is named after Dr. George D. Butler, Jr., my collecting companion and colleague in the Department of Entomology.

\section{Emelinus huachucanus sp.n.}

Brown, the elytra paler in an obscure pattern as follows: an oblique zone on 2nd quarter of each elytron, approaching suture behind; a smaller zone at apical 3/4, transverse and extending approximately $1 / 3$ across each elytron, narrowly and obscurely connected behind along suture to a small zone at apical 5th. Rami of male antennae short, almost uniform in length, all less than $1 / 5$ as long as the antenna. Only E. breviramus (Champ.) approaches this condition and, if the illustration in the Biologia is correct, the longest ramus is $1 / 4$ as long as the antenna in that species.

Holotype male: length $3.51 \mathrm{~mm}$.; maximum width of elytra ca. $1.06 \mathrm{~mm}$. Antennae $2.12 \mathrm{~mm}$. long, 0.60 as long as the body. Head elliptical, $0.53 \mathrm{~mm}$. long to front edge of eyes, $0.77 \mathrm{~mm}$. wide across eyes. What little surface is not covered by the eyes is smooth, shiny, deeply and densely punctured, with moderately sparse, subdecumbent pubescence. Eyes very large, $0.50 \times 0.42 \mathrm{~mm}$., separated by only ca. $0.03 \mathrm{~mm}$., deeply excised for the insertion of 
the antennae. Fronto-clypeal suture strong; clypeus and labrum with finer and sparser punctures and pubescence than rest of head. Last segment of maxillary palpi $0.26 \times 0.14 \mathrm{~mm}$. Details of antennal segments almost exactly as in butleri, except that the rami are of different proportions. Measurements (to a total length of 1,000 units) : $73 / 49,36 / 36,115 / 35,85 / 27,85 / 24,91 / 23,85 / 23$, $79 / 22,85 / 27,85 / 27,182 / 42$. Rami, from IV to $\mathrm{x}: 121$, $176,182,188,182,176,158$. Individual rami noticeably thickened apically, from ca. $0.02 \mathrm{~mm}$. at base to ca. 0.04 $\mathrm{mm}$. at apex. These figures are similar to those of butleri but the shorter rami here accentuate the thickening. Segment XI is 24 units wide at base, gradually expanding to the knob, 42, at 0.6 of the way from the base, then constricts and tapers gradually to the apex. Pronotum very similar in detail to that of butleri, except that there is a pair of feeble impressions on the disc just anterior to the slight postero-median elevations, within the basal third. Details of scutellum and elytra likewise almost identical with butleri, except for the color pattern of the elytra. The punctures do not appear as distinct, because of the paler ground color. Pronotum $0.64 \times 0.64 \mathrm{~mm}$.; elytra $2.34 \mathrm{~mm}$. long, $0.94 \mathrm{~mm}$. wide at humeri, ca. $1.06 \mathrm{~mm}$. at widest. Details of underside also much as in butleri, but thorax pale and legs, except coxae and tarsi, mainly dark. First segment of posterior tarsi $0.44 \mathrm{~mm}$. long, rest together $0.30 \mathrm{~mm}$.; ratio of I to rest 1.48: 1 .

Allotype female: The remarks about the comparison of male and female under butleri apply equally well here. On a specimen $3.3 \mathrm{~mm}$. long the antennae are $1.37 \mathrm{~mm}$. long, or 0.40 as long as body. The individual measurements of the segments (to a total of 1,000 units) are: $130 / 56,75 / 47,112 / 43,94 / 51,79 / 54,69 / 54,75 / 54,75 / 58$, $75 / 65,75 / 66,140 / 82$. The eyes are $0.37 \times 0.31 \mathrm{~mm}$. and are separated by $0.18 \mathrm{~mm}$. The first segment of the posterior tarsi is $0.41 \mathrm{~mm}$. long, the rest together $0.24 \mathrm{~mm}$., giving a ratio of the first to the rest of 1.68: 1 .

Holotype male and allotype female: Ramsey Canyon, Huachuca Mts., Cochise Co., Arizona, July 12, 1955, F. G. 
Werner and G. D. Butler, deposited in the Mcz. 102 male and 19 female paratypes from the same locality, July 12 and 13,1955 , in the collections of the $\mathrm{MCZ}$, University of Arizona, U.S. National Museum, California Academy of Sciences and the author. One female paratype collected in Huachuca Mts., Arizona, July 20, 1937, D. J. \& J. N. Knull returned to Ohio State.

There is some variation in the extent of the pale markings on the elytra, these being reduced to not much more than dots in some and broadened so that they are very conspicuous in others. Total length ranges from 2.8 to $3.7 \mathrm{~mm}$. in the males and from $3.1 \mathrm{~mm}$. to $3.8 \mathrm{~mm}$. in the females. 

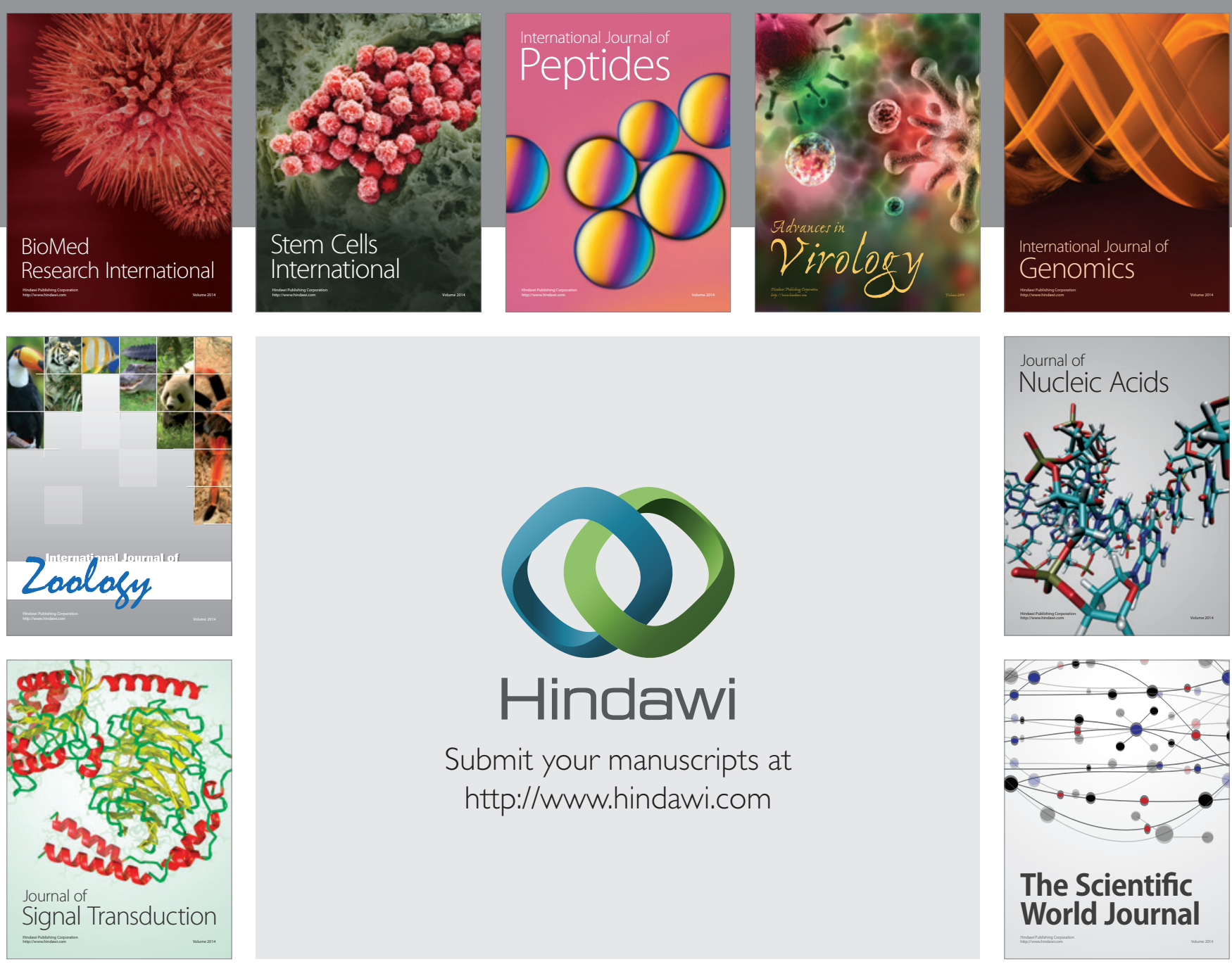

Submit your manuscripts at

http://www.hindawi.com
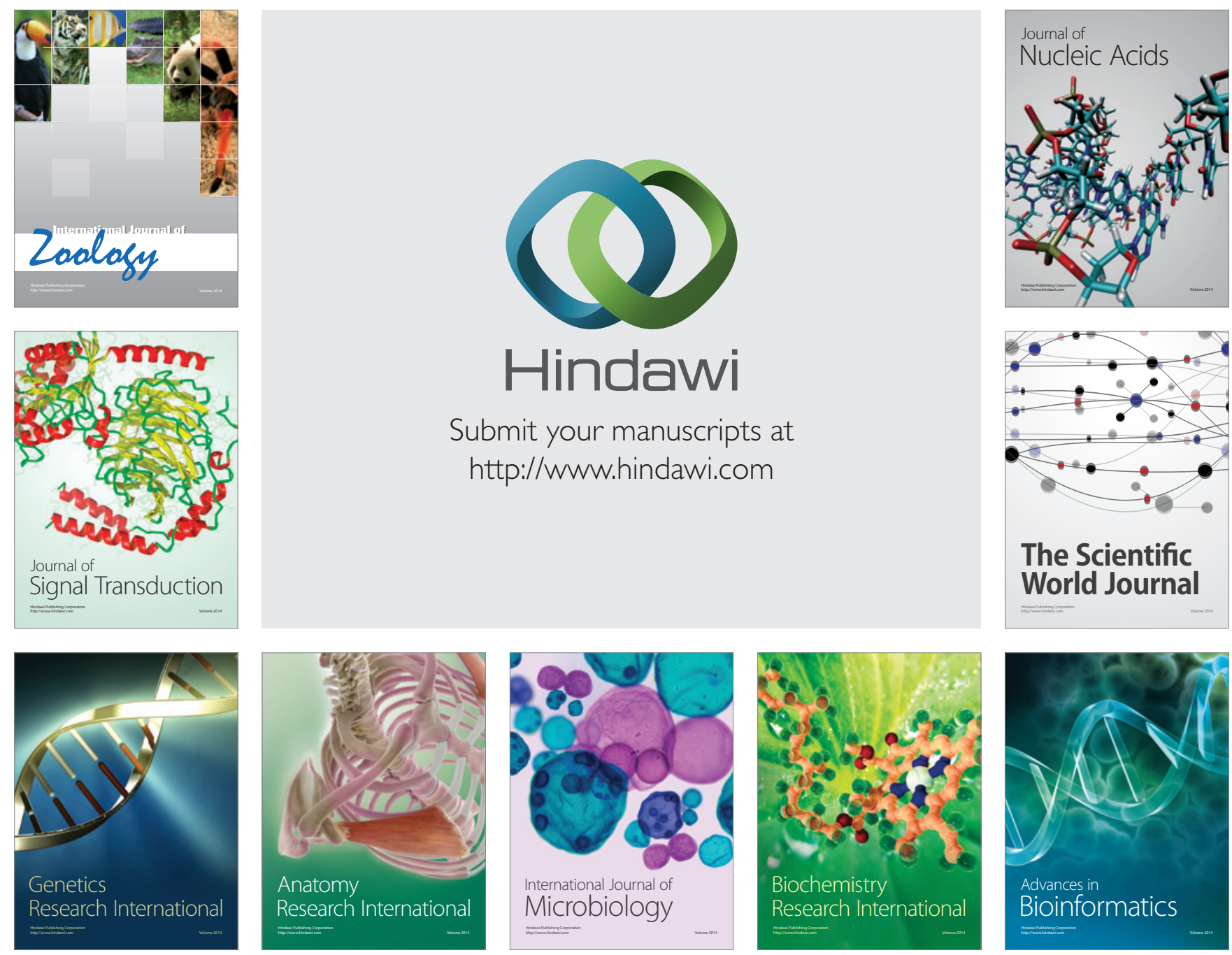

The Scientific World Journal
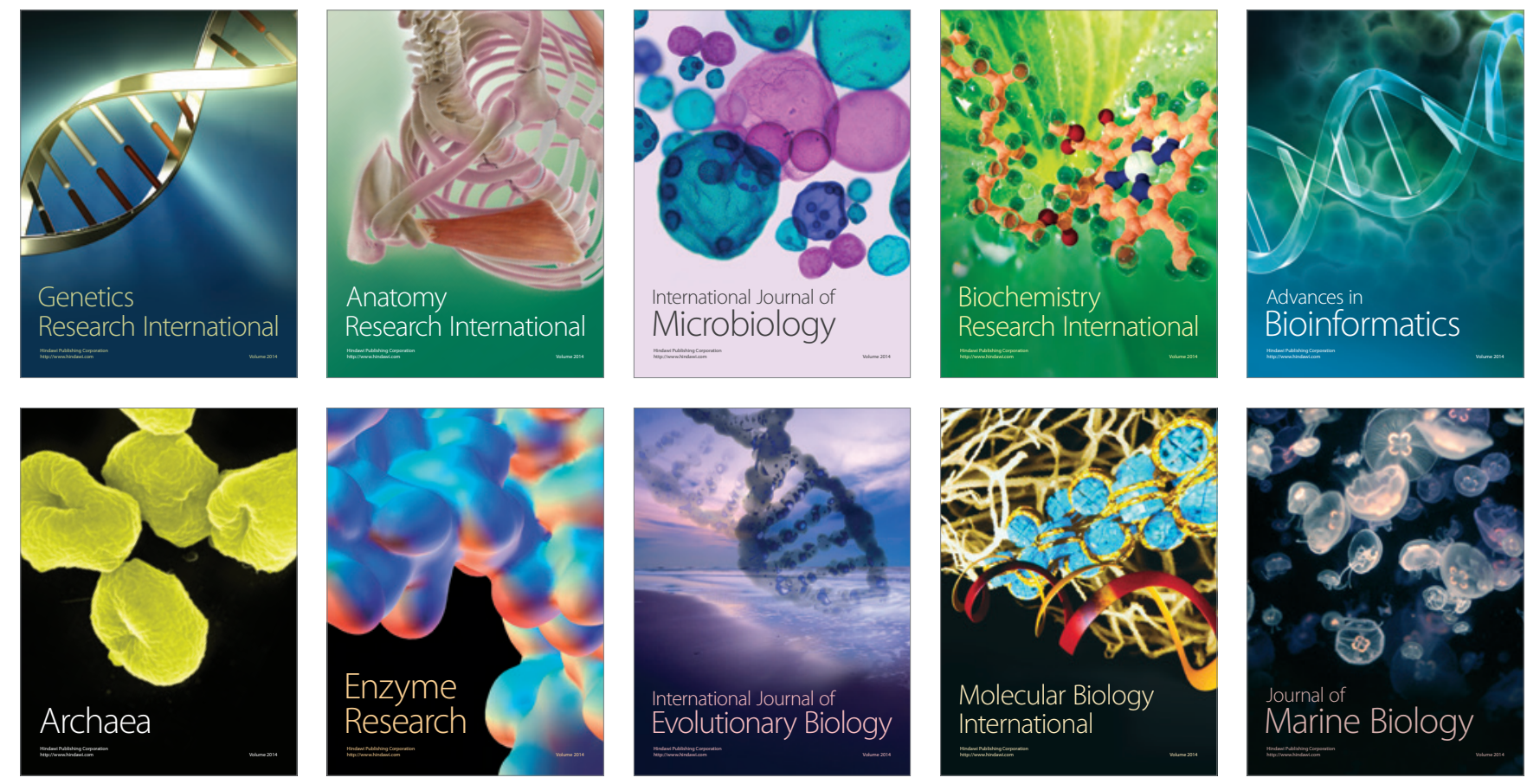